УДК 378.011.3 051:373.3]:005.963.1:37.064.3

DOI:

Крістіна Петрик, аспірант кафедри професійної освіти, трудового навчання та технологій Бердянського державного педагогічного університету

\title{
ГОТОВНІСТЬ МАЙБУТНІХ УЧИТЕЛІВ ПОЧАТКОВОЇ ШКОЛИ ДО ОРГАНІЗАЦІЇ ІНТЕРАКТИВНОЇ НАВЧАЛЬНОЇ ВЗАСМОДІЇ УЧНІВ
}

У статті синтезовано й подано визначення дефініції "готовність майбутніх учителів початковоі школи до організації інтерактивної навчальної взаємодії учнів”. Внесено деякі уточнення щодо трактування понять “професійна підготовка", “готовність”, “професійна готовність”, щцо поглиблює розуміння ключового поняття "готовність майбутніх учителів початкової школи до організації інтерактивної навчальної взаємодії учнів” та схарактеризовано його структурні компоненти: иілемотивачійний, змістовно-прочесуальний та рефлексивно-корекційний.

Ключові слова: професійна підготовка; готовність; професійна готовність; готовність майбутніх учителів початкової школи до організації інтерактивної навчальної взаємодії учнів; структурні компоненти готовності.

Jim. 10.

Kristina Petryk, Postgraduate Student of the Professional Education, Labor Training and Technologies Department Berdyansk State Pedagogical University

\section{THE READINESS OF THE FUTURE PRIMARY SCHOOL TEACHERS TO THE ORGANIZATION OF INTERACTIVE EDUCATIONAL INTERACTION OF PUPILS}

In the article on the basis of the analysis of psychological and pedagogical literature the author describes and defines the essence of the concept "the readiness of a future primary school teachers to the organization of interactive educational interaction of pupils". Some clarifications have been made regarding the interpretation of the concepts "the professional training", "the readiness", "the professional readiness", which deepens the understanding of the key concept "the readiness of a future primary school teachers to the organization of interactive educational interaction of pupils" and describes its structural components: whole-motivational, content-procedural and reflexive-correctional.

An essential characteristic of the outcome of the training, as well as an important factor in the successful organization of interactive educational interaction of pupils is the willingness of future teachers to this activity, and its formation and development - the necessary components of professional training of future specialists.

The author emphasizes the fact that modern society puts new requirements to the personality of the future primary school teacher as a subject of value relations, with creative scientific and pedagogical thinking, with a certain system of personality and professional qualities, necessary knowledge, skills and abilities, which will contribute to the formation of the readiness of a future primary school teachers to the organization of interactive educational interaction of pupils and will ensure the possibility for choosing the behavioral alternatives, successful socialization of future specialists, development of their creative potential, initiative, personal self-improvement. According to this, the reform of higher pedagogical education is based on the principles of humanization, which involves the readiness of the teacher not only to apply the modern interactive teaching technologies, but also to establish interpersonal relationships based on respect for the personal position of each participant.

The readiness of a future primary school teachers to the organization of interactive educational interaction of pupils is an important element in the professional formation of the teacher's personality, one of the parameters of vocational and pedagogical readiness and is an indicator of professionalism.

The result of the research is the generalization of the concept "the readiness of a future primary school teachers to the organization of interactive educational interaction of pupils", which is considered as a holistic sustainable complex education, covering the system of professional, psychological and pedagogical and methodological knowledge, skills and abilities of the organization of educational activities of junior pupils, is not only in the presence of knowledge and the formation of abilities, but also in that the activity of the teacher who remains in the subjective position, was directed to the student's content in an active position subject.

Keywords: the professional training; the readiness; the professional readiness; the readiness of the future primary school teachers to the organization of interactive educational interaction of pupils; the structural components of readiness.

$\Pi$ остановка проблеми. Інтеграція вищої освіти України в європейський та світовий освітній простір актуалізує проблему вдосконалення професійної підготовки майбутнього педагога. В країнах Європейського Союзу на етапі професійної підготовки вчителів 


\section{ГОТОВНІСТЬ МАЙБУТНІХ УЧИТЕЛІВ ПОЧАТКОВОЇ ШКОЛИ ДО ОРГАНІЗАЦІЇ ІНТЕРАКТИВНОЇ НАВЧАЛЬНОЇ ВЗАСМОДІЇ УЧНІВ}

чіткою є спрямованість на інноваційний характер навчання. Поняття “інноваційність” стосується не тільки створення та поширення новацій, а й зміни в способі діяльності та стилі мислення. На відміну від репродуктивного навчання, інноваційний підхід до підготовки вчителів передбачає створення можливостей для виявлення їхньої активної позиції, засвоєння нового досвіду на основі цілеспрямованого формування творчого й критичного мислення, набуття навичок використання інструментарію навчальнодослідної діяльності. Серед основних інновацій у галузі освіти вирізняються інтерактивні технології навчання, проте використання їх у практиці початкової школи носить фрагментарний характер; педагоги не завжди готові до методично обгрунтованого застосування інтерактивних технологій навчання, тому, на нашу думку, вкрай необхідно посилити підготовку вчителів початкової школи у вищих навчальних закладах у цьому аспекті.

Сутнісною характеристикою результату підготовки, а також важливим чинником успішної організації інтерактивної навчальної взаємодії учнів є готовність майбутніх учителів до цієї діяльності, а їі формування та розвиток $\epsilon$ необхідними компонентами професійної підготовки майбутніх фахівців. Готовність як системна якість особистості майбутнього вчителя формується в процесі підготовки у ВНЗ.

Аналіз останніх досліджень і публікацій. Проблема підготовки майбутніх учителів початкової школи грунтовно презентована в дослідженнях вітчизняних фахівців, зокрема В. Бондаря, Н. Глузман, Л. Коваль, М. Марусинець, І. Пальшкової, Л. Петухової, І. Осадченко, та ін. Теоретично обгрунтовано та експериментально перевірено шляхи удосконалення процесу підготовки майбутнього педагога (Б. Долинський, О. Ліннік, С. Мартиненко, Н. Мар'євич, Л. Петриченко, О. Писарчук та ін.), сутність формування готовності та показників ¥і1 сформованості (А. Алексюк, Л. Кондрашова, Н. Кузьміна, В. Сластьонін та ін.), формування професійної готовності майбутнього вчителя початкових класів (О. Біда, О. Матвієнко, О. Комар, І. Шапошнікова та ін.). Проте, незважаючи на значний інтерес учених до зазначеного питання, проблема формування готовності майбутніх учителів початкової школи до організації інтерактивної навчальної взаємодії учнів в педагогічній теорії й практиці розроблена недостатньо.

Метою статті $є$ визначення сутності поняття “готовність майбутніх учителів початкової школи до організації інтерактивної навчальної взаємодії учнів" та характеристика структурних компонентів готовності.

Виклад основного матеріалу. Інноваційні процеси, пов'язані з модернізацією всієї освітньої системи в новому столітті, висувають нові вимоги до діяльності педагогів. Учені (О. Абдуліна, Н. Кузьміна, Н. Тализіна та ін.) зазначають, що професійна підготовка майбутніх учителів процес формування й набуття настанов, знань та вмінь, необхідних спеціалісту для належного виконання спеціальних завдань навчальновиховного процесу. Інші науковці (І. Богданова, I. Зязюн, Е. Карпова, Н. Кічук, З. Курлянд, Р. Хмелюк, О. Цокур та ін.) наголошують на тому, що професійна підготовка майбутніх учителів це цілісний процес засвоєння й закріплення загальнопедагогічних та соціальних знань, умінь і навичок.

У нашому дослідженні важлива змістовна єдність понять “готовність” і “підготовка”, яка виражається у такій дефініції: “підготовка - це формування готовності суб'єкта до діі”.

Відомо, що результатом, а отже і метою професійної підготовки майбутніх учителів початкової школи до організації інтерактивної навчальної взаємодії учнів $є$ готовність студентів до здійснення навчальної взаємодії, найбільш активна фаза формування якої співпадає 3 періодом навчання в педагогічномузакладі освіти, а завершується - під час самостійної педагогічної діяльності.

Визначимо сутність поняття готовності та на його основі надамо власне визначення поняття “готовність майбутніх учителів початкової школи до організації інтерактивної навчальної взаємодії учнів".

Проблемами готовності у педагогіці, а саме виявленню особливостей готовності в різних видах діяльності присвячені роботи О. Абдулліної, А. Бистрюкової, О. Бойко, Ю. Васильєва, М. Гадецького, В. Гребневої, О. Демидовича, К. Дурай-Новакова, С. Іванової, Л. Кандибовича, Д. Каца, О. Ковальова, Л. Кондрашової, В. Копоруліної, Л. Кутепова, А. Линенко, Р. Лучечко, С. Максименка, О. Мармази, В. Сластьоніна, М. Сметанського, Р. Хмелюка, А. Шевченко, Д. Узнадзе; професійну готовність досліджували - Г. Балл, О. Бикова, А. Деркач, О. Коберник, Д. Мазоха, професійно-педагогічну - В. Бондар, А. Капська, С. Коришенко, I. Пастир, I. Підласий, О. Ярошенко та ін. Доцільно відмітити, що дослідники встановили, що саме при формуванні готовності особистості вчителя відбувається розвиток індивідуальності, 


\section{ГОТОВНІСТЬ МАЙБУТНІХ УЧИТЕЛІВ ПОЧАТКОВОЇ ШКОЛИ ДО ОРГАНІЗАЦІЇ ІНТЕРАКТИВНОЇ НАВЧАЛЬНОЇ ВЗАСМОДІЇ УЧНІВ}

професійної компетентності, загальної професійної культури, професійне та духовне збагачення, що сприяє вдосконаленню управління та стилю роботи.

Підкреслимо, що готовність є первинною, фундаментальною умовою успішної реалізації педагогічної діяльності, її складником, що формується та виявляється у процесі навчання.

Проблема формування готовності майбутніх учителів початкової школи до організації інтерактивної навчальної взаємодії учнів, передбачає, насамперед, угочнення іiї категоріального апарату: “готовність”, “професійна готовність”, “готовність майбутнього вчителя початкової школи до організації інтерактивної навчальної взаємодії учнів".

Готовність до професійного саморозвитку стимулює особистість, розвиток іï якостей, психічну діяльність; сприяє розвитку активності особистості, формуванню досвіду творчої професійної педагогічної діяльності педагога, сприяє підвищенню рівня його самостійності в діяльності, мобілізує особистість на виконання поставлених цілей й завдань, розширює науковий кругозір, підвищує відповідальність педагога за результати своєї діяльності, тобто готовність є умовою розвитку суб' єктних якостей педагога $[10,216]$.

Достатньо глибокий аналіз готовності до педагогічної праці містять роботи В. Сластьоніна, який визначає дане поняття “... як складне особистісне утворення, що виступає важливою характеристикою професіоналізму вчителя і $\epsilon$ особливим психічним станом, який передбачає наявність у суб'єкта образу, структури певної дії та професійної спрямованості свідомості на їі виконання, а також містить різні настанови на усвідомлення педагогічного завдання, моделі ймовірної поведінки, визначення спеціальних способів діяльності, оцінку своїх можливостей у ïх співвідношенні 3 майбутніми труднощами й необхідністю досягнення певного результату". Готовність як складне психологічне явище, крім необхідних знань, умінь і навичок, включає не тільки адекватні вимоги до професійної діяльності, якостей особистості і здібностей, а й пізнавальні (розуміння професійних завдань, оцінка їх значущості), мотиваційні (інтерес до професії, прагнення домогтися успіху) та вольові (подолання сумнівів, вміння мобілізувати свої сили) компоненти, а отже, передбачає наявність когнітивної, операційної та аксіологічної складових [12, 79].

Процес готовності до педагогічної діяльності Л. Коваль розглядає як частину професійної підготовки майбутнього вчителя, інтегральне, багатоаспектне утворення, яке включає в себе низку компонентів, адекватних вимогам, умовам та змісту педагогічної діяльності. Більш детально автор розглядає готовність майбутніх учителів до технологічного навчання в початковій школі та визначає їі як інтегровану особистісно-професійну якість, що характеризує певний рівень розвитку їхньої технологічної компетентності, взаємодія компонентів якої забезпечує оволодіння технологічно-проектувальними вміннями з метою організації технологічного процесу навчання в початковій школі [5, 92].

У дослідженні О. Ліннік під готовністю до суб'єкт-суб'єктної взаємодії розуміється інтегральне ієрархічне утворення особистості педагога, що характеризується сформованою суб'єктною позицією, обізнаністю у закономірностях та способах організації взаємодії, комунікативною відкритістю, здатністю до рефлексивного управління [8, 124].

На думку А. Линенко, готовність розуміється як цілісне утворення, яке характеризує емоційнокогнітивну і вольову мобільність суб'єкта в момент його включення в діяльність певного спрямування. У цьому випадку - педагогічну. Готовність не $є$ вродженою, а виникає в результаті певного досвіду людини, що грунтується на формуванні іiі позитивного ставлення до професійної діяльності, усвідомленні мотивів і потреб у ній $[7,56]$.

У своїх роботах дослідниця виділяє такі прояви готовності: позитивне ставлення до праці вчителя; певний рівень оволодіння педагогічними знаннями, вміннями та навичками; самостійність у розв'язанні професійних завдань; розвиток педагогічних здібностей; наявність професійнопедагогічної спрямованості особистості; моральні риси особистості $[6,128]$.

Під поняттям “готовність майбутнього вчителя до забезпечення педагогічної взаємодії” О. Матвієнко розуміє сукупність особистісних, психологічних і професійних особливостей вчителя, що охоплюють мотиваційну, змістовопроцесуальну та дієво-оперативну сфери педагогічної діяльності, яка дає йому змогу успішно реалізувати цілі гуманістичного виховання. Автор стверджує, що іiі доцільно розглядати як цілісну систему, що вибудовується як інтегральне ціле на основі загальнопедагогічного (є складові професійної загальнопедагогічної готовності), особливого (має свою специфіку, зумовлену особливостями й закономірностями процесу формування готовності педагога до певного виду діяльності) та індивідуального (відображає залежність готовності від підготовки, 


\section{ГОТОВНІСТЬ МАЙБУТНІХ УЧИТЕЛІВ ПОЧАТКОВОЇ ШКОЛИ ДО ОРГАНІЗАЦІЇ ІНТЕРАКТИВНОЇ НАВЧАЛЬНОЇ ВЗАЄМОДІЇ УЧНІВ}

особистісно-професійних характеристик учителя) $[9,206]$.

У дослідженнях М. Дьяченка та Л. Кандибовича готовність розглядається як якість особистості та складне психологічне утворення 3 такими структурними компонентами:

1) мотиваційний (позитивне ставлення до професії, інтерес до неї та інші досить стійкі професійні мотиви);

2) орієнтаційний (знання й уявлення про особливості й умови професійної діяльності, піi вимоги до особистості);

3) операційний (володіння способами та прийомами професійної діяльності, необхідними знаннями, навичками, уміннями, процесами аналізу, синтезу, порівняння, узагальнення тощо);

4) вольовий (самоконтроль, уміння керувати діями, що є основним при виконанні трудових обов'язків);

5) оцінний (самооцінка своєї професійної підготовленості й відповідність процесу виконання професійних завдань оптимальним трудовим зразкам) $[3,51]$.

У зв'язку з тим, що готовність до навчання певного предмету $є$ частиною готовності вчителя до професійної діяльності, вважаємо необхідним звернути особливу увагу на дослідження готовності спеціаліста педагогічної спрямованості та прослідкувати як розглядається іiї сутність та структура.

За визначенням К. Дурай-Новакової, професійна готовність $є$ не лише результатом, але й метою професійної підготовки, початковою та основною умовою ефективної реалізації можливостей кожної особистості. Готовність до професійної діяльності розглядається вченою як стан, який передує певній діяльності та в якому особистість майбутнього вчителя, концентруючись, досягає найвищого ступеня розвитку, якщо вона цього бажає; стан, який виявляється перед, під час і по завершенні виконання педагогічного завдання. Сам процес формування готовності має складну динамічну структуру, до якої входить сукупність емоційних, вольових, мотиваційних, пізнавальних, операціональних аспектів, властивостей, утворень, станів психіки особистості у їх співвідношенні з зовнішніми ситуаційними умовами й майбутніми завданнями $[2,17]$.

У деяких сучасних авторських дефініціях простежується визначення готовності через процес підготовки. Такий зв'язок очевидний у визначенні готовності студентів до організації навчального діалогу, сформульованому I. Глазковою, у якому вона постає як “безпосередній результат професійної підготовки майбутнього вчителя, вкладне інтегративне особистісне утворення, що забезпечує доцільність та можливість організації суб'єкт-суб' єктного спілкування" [1, 8].

Професійну готовність І. Зязюн розуміє як сформованість особистісних якостей, високий рівень спеціальних і загальних знань, здатність вирішувати різні педагогічні задачі, здатність керувати діяльністю, гуманістичну позицію вчителя [4, 258].

Вартим уваги в цьому контексті видається нам судження П. Скляра, що професійна готовність майбутнього вчителя $\epsilon$ найважливішим складником загальної підготовки особистості фахівця. Науковець розглядає професійну готовність через професійну майстерність, професійну компетентність, оволодіння управлінською технікою і технологією, що “слугує показником соціальної зрілості майбутнього фахівця і $є$ професійно важливою якістю, яка передбачає наявність психологічних знань, умінь i особистісних рис, що характеризують спрямованість на ефективну взаємодію з колегами упроцесі реалізації професійної діяльності” $[11,149]$.

Таким чином, професійна готовність майбутніх учителів є передумовою їх ефективної діяльності після закінчення вищого педагогічного навчального закладу. Вона розкриває інтегративну якість особистості й допомагає молодому фахівцеві успішно виконувати свої обов'язки, правильно використовувати знання, досвід, зберігати самоконтроль і ефективно здійснювати навчальну взаємодію молодших школярів. Професійна готовність - це визначальна особливість швидкої адаптації до умов праці, подальшого професійного вдосконалення й підвищення кваліфікації майбутнього вчителя.

Цілісність цього утворення визначається повноцінним розвитком його складових компонентів: ціле-мотиваційного, змістовнопроцесуального, рефлексивно-корекційного, що корелюються $з$ педагогічними умовами підготовки майбутніх учителів початкової школи до організації інтерактивної навчальної взаємодії учнів.

Готовність майбутніх учителів початкової школи до організації інтерактивної навчальної взаємодії учнів є важливим елементом фахового становлення особистості педагога, одним із параметрів професійно-педагогічної готовності та $\epsilon$ показником професіоналізму.

На основі теоретичних узагальнень нами встановлено, що готовність до педагогічної 


\section{ГОТОВНІСТЬ МАЙБУТНІХ УЧИТЕЛІВ ПОЧАТКОВОЇ ШКОЛИ ДО ОРГАНІЗАЦІЇ ІНТЕРАКТИВНОӤ НАВЧАЛЬНОЇ ВЗАСМОДІЇ УЧНІВ}

діяльності, як і готовність до будь-яких видів діяльності, досліджується за їі складовими. Виходячи з багатоаспектного поля визначень змісту й особливостей готовності майбутніх учителів початкової школи до організації інтерактивної навчальної взаємодії учнів, вважаємо за необхідне виокремити іiї стрижневі компоненти, зокрема:

- ціле-мотиваційний, сутністю якого $\epsilon$ формування позитивного ставлення у майбутніх учителів початкової школи до організації інтерактивної навчальної взаємодії учнів, стійке прагнення розвивати суб'єкт-суб'єктну взаємодію, оновлення та збагачення знань 3 проблем розвитку початкової освіти. Цілемотиваційний компонент, що відображає професійно-особистісне самовизначення, передбачає наявність сформованості духовних, морально-етичних, пізнавальних потреб та інтересів, а також вольових якостей i спрямованості на творчість; передбачає сформовану внутрішню мотивацію до інтерактивної навчальної взаємодії; потребу в саморозвитку та в самовдосконаленні, наявність суб' єктної позиції, професійно важливих якостей (креативність, цілеспрямованість, працездатність, відповідальність, наполегливість тощо), інтерактивна спрямованість особистості.

- змістовно-процесуальний, що передбачає засвоєння загальнопедагогічних та дидактикометодичних знань і вмінь щодо підготовки майбутніх учителів початкової школи до організації інтерактивної навчальної взаємодії учнів; уміння обирати оптимальні форми та методи навчання молодших школярів відповідно до виду, теми та мети заняття; володіння технологіями професійної діяльності щодо моделювання та проведення занять 3 метою розвиткуінтерактивної навчальної взаємодії учнів. Наявність цього компонента у структурі готовності майбутніх учителів початкової школи до організації інтерактивної навчальної взаємодії учнів у початковій школі сприяє збагаченню професійного потенціалу студента, оскільки необхідні вміння і навички застосування інтерактивних форм і методів роботи дозволяють ефективніше розв'язувати завдання навчання, виховання і розвитку учнів.

- рефлексивно-корекційний, що є вираженням здатності суб'єкта навчально-виховного процесу до самоспостереження, самооцінювання своєї діяльності як головна передумова реалізації зворотного зв'язку, виявляється у здатності майбутніх учителів початкової школи здійснювати рефлексивну педагогічну діяльність, прагненні до самовдосконалення та самоаналізу в галузі педагогічної освіти, використанні нових підходів у проведенні занять. Для успішної рефлексії майбутній фахівець повинен розвинути в собі педагогічну самосвідомість, самооцінку, самоконтроль, набути професійної ідентичності.

Доцільно зазначити, що розглянуті вище компоненти зазначеної готовності відображають основні тенденції ефективного результату професійної підготовки майбутніх учителів початкової школи до організації інтерактивної навчальної взаємодії учнів.

Отже, аналіз проблеми професійної підготовки майбутніх учителів початкової школи до організації інтерактивної навчальної взаємодії учнів дозволив установити взаємозв'язки процесу підготовки і стану готовності. Підготовка виступає засобом формування готовності до організації інтерактивної навчальної взаємодії учнів, готовність $€$ результатом і показником якості підготовки, що реалізується і перевіряється в діяльності; діяльність є метою підготовки і водночас виконує функції іiі регулювання та корекції. Специфікою різних визначень готовності $\epsilon$ те, що вони не є суперечливими, а радше взаємодоповнюючими. Усе це розширює й поглиблює уявлення про складність і багатогранність феномена готовності. Тож на його основі надамо власне визначення поняття “готовності майбутніх учителів початкової школи до організації інтерактивної навчальної взаємодії учнів".

Висновки. Готовність майбутніх учителів початкової школи до організації інтерактивної навчальної взаємодії учнів розглядається нами як цілісне утворення, що охоплює систему загальнопедагогічних і дидактико-методичних знань, умінь та навичок щодо організації інтерактивної навчальної взаємодії учнів та полягає у тому, щоб діяльність педагога, що залишається в суб'єктивній позиції, спрямовувалася на утримання учня в активній позиції суб'єкта.

Структурними компонентами готовності майбутніх учителів початкової школи до організації інтерактивної навчальної взаємодії учнів $\epsilon$ ціле-мотиваційний, змістовнопроцесуальний, рефлексивно-корекційний.

Перспективи подальших досліджень. Проведене дослідження не вичерпує всіх аспектів означеного питання. Черговим кроком подальшого дослідження вважаємо розкриття критеріїв та рівнів сформованості готовності майбутніх учителів початкової школи до організації інтерактивної навчальної взаємодії учнів. 


\section{ГОТОВНІСТЬ МАЙБУТНІХ УЧИТЕЛІВ ПОЧАТКОВОӤ ШКОЛИ ДО ОРГАНІЗАЦІЇ ІНТЕРАКТИВНОЇ НАВЧАЛЬНОЇ ВЗАЕМОДІЇ УЧНІВ}

\section{ЛІТЕРАТУРА}

1. Глазкова І. Я. Підготовка майбутнього вчителя до організації навчального діалогу в професійній діяльності: автореф. дис. на здобуття наук. ступеня канд. пед. наук: спец. 13.00.04 “Теорія і методика професійної освіти” / Ірина Яківна Глазкова. - Харків, 2004. -21 с.

2. Дурай-НоваковаК. М. Формированиепрофессиональной готовности студентов к педагогической деятельности: автореф. дисс. на соискание науч. степени доктора пед. наук: спец. 13.00.01 “Общая педагогика, история педагогики и образования” / Карина Михайловна Дурай-Новакова. - М., 1983. - 32 с.

3. Дьяченко М. И. Психологические проблемы готовности к деятельности / М. И. Дьяченко, Л. А. Кандыбович. - Минск: БГУ, 1976. - 175 с.

4. Зязюн I. А. Педагогічна майстерність: підруч. / І. А. Зязюн, Л. В. Крамущенко, І. Ф. Кривонос та ін. // За ред. І. А. Зязюна. - [2-ге вид., допов. і переробл.]. - К.: Вища шк., 2004. - 422 с.

5. Коваль Л. В. Професійна підготовка майбутніх учителів у контексті розвитку початкової освіти: монографія / Л. В. Коваль. - [2-е вид., перероб. і допов.]. - Донецьк: ЛАНДОН-ХХІ, 2012. - 343 с.

6. Линенко А. Ф. Готовність майбутніх учителів до педагогічної діяльності / А. Ф. Линенко // Педагогіка і психологія. - 1995. - № 1. - С. 125-132.

7. Линенко А. Ф. Теорія та практика формування готовності студентів педагогічних вузів до професійної діяльності: дис. ... доктора пед. наук: спец. 13.00.01 “Загальна педагогіка та історія педагогіки”, спец. 13.00.04 “Теорія і методика професійної освіти” / Алла Францівна Линенко. - К., 1996. - 378 c.

8. Ліннік О. О. Майбутній учитель як суб'єкт педагогічної взаємодії: підготовка до співробітництва 3 молодшими школярами: монографія / Олена Олегівна Ліннік. - К.: Видавничий Дім “Слово”, 2014. $-304 \mathrm{c}$.

9. Матвієнко О. В. Підготовка майбутніх учителів до педагогічної взаємодії: монографія / Олена Валеріївна Матвієнко. - К.: НПУ ім. М. П. Драгоманова, 2009. - 384 c.

10. Пехота Е. Н. Индивидуализация профессиональнопедагогической подготовки учителя: дисс. ... доктора пед. наук: спец. 13.00.04 “Теория и методика профессионального образования" / Елена Николаевна Пехота. - К, 1997. - 401 с.

11. Скляр П. П. Гуманізація освіти у життєвих перспективах майбутніх інженерів: монографія / П. П. Скляр. - Луганськ: Вид-во СНУ ім. В. Даля, 2007. - 288 c.

12. Сластенин В. А. Профессиональная подготовка учителя в системе высшего педагогического образования / В. А. Сластенин. - М.: МГПИ, 1992. $180 \mathrm{c}$.

\section{REFERENCES}

1. Hlazkova, I. Ya. (2004). Pidhotovka maibutnoho vchytelia do orhanizatsii navchalnoho dialohu $\mathrm{v}$ profesiinii diialnosti [Preparation of a future teacher for organization of a training dialogue in professional activity]. Extended abstract of candidate's thesis. Kharkiv, 21 p. [in Ukrainian].

2. Duray-Novakova, K. M. (1983). Formirovanie professionalnoy gotovnosti studentov $\mathrm{k}$ pedagogicheskoy deyatelnosti [Formation of professional readiness of students for pedagogical activity]. Extended abstract of candidate's thesis. Moscow, 32 p. [in Russian].

3. Dyachenko, M. I. \& Kandybovich, L. A. (1976). Psikhologicheskie problemy gotovnosti $k$ deyatelnosti [Psychological problems of the readiness for activity]. Minsk: BGU Publ., 175 p. [in Russian].

4. Zyazyun, I. A., Kramushchenko, L. V. \& Kryvonos, I. F. (2004). Pedahohichna maysternist [The pedagogical skill]. (Ed.). I. A. Zyazyun, vol. 2, redone and supplemente. Kyiv: Vyshcha shk. Publ., 422 p. [in Ukrainian].

5. Koval, L. V. (2012). Profesiyna pidhotovka maybutnikh uchyteliv u konteksti rozvytku pochatkovoyi osvity [Professional training of future teachers in the context of the development of elementary education]. vol. 2, redone and supplemented. Donetsk: LANDON-XXI Publ., 343 p. [in Ukrainian].

6. Lynenko, A. F. (1995). Hotovnist maybutnikh uchyteliv do pedahohichnoyi diyalnosti [The readiness of the future teachers for pedagogical activity]. Pedagogy and Psychology, no. 1. pp. 125-132. [in Ukrainian].

7. Lynenko, A. F. (1996). Teoriya ta praktyka formuvannya hotovnosti studentiv pedahohichnykh vuziv do profesiynoyi diyalnosti [Theory and practice of formation of readiness of students of pedagogical institutes for professional activity]. Doctor's thesis. Kyiv, 378 p. [in Ukrainian].

8. Linnik, O. O. (2014). Maibutnii uchytel yak subiekt pedahohichnoi vzaiemodii: pidhotovka do spivrobitnytstva z molodshymy shkoliaramy [Future teacher as a subject of pedagogical interaction: preparation for cooperation with junior schoolchildren]. Kyiv, Vydavnychyi Dim “Slovo", 304 p. [in Ukrainian].

9. Matviienko, O. V. (2009). Pidhotovka maibutnikh uchyteliv do pedahohichnoi vzaiemodii [Preparation of future teachers for pedagogical interaction]. Kyiv: NPU im. M. P. Drahomanova, 384 p. [in Ukrainian].

10. Pekhota, Ye. N. (1997). Individualizatsiya professionalno-pedagogicheskoy podgotovki uchitelya [Individualization of teacher's professional and pedagogical training]. Doctor's thesis. Kyiv, 401 p. [in Russian].

11. Sklyar, P. P. (2007). Humanizatsiya osvity u zhyttyevykh perspektyvakh maybutnikh inzheneriv [Humanization of education in the life prospects of future engineers]. Luhansk: Vyd-vo SNU im. V. Dalya, 288 p. [in Ukrainian].

12. Slastenin, V. A. (1992). Professionalnaya podgotovka uchitelya $v$ sisteme vysshego pedagogicheskogo obrazovaniya [Professional training of the teacher in the system of higher pedagogical education]. Moscow: MGPI Publ., 180 p. [in Russian].

Стаття надійшла до редакції 04.04.2018 